\title{
DEVELOPMENT STRATEGY OF KARYA NUGRAHA MULTIPURPOSE COOPERATIVE
}

\author{
Kusumaraya Deny*, Baga Lukman M., Sasongko Hendro \\ School of Business, Bogor Agricultural University, Indonesia \\ *E-mail: deny kusumaraya@yahoo.co.id
}

\begin{abstract}
The main objective of this research is to map the nine elements of Business Canvas Model owned by the Karya Nugraha Multipurpose Cooperative located in Cigugur Sub-District, Kuningan District, West Java Province. Next, it draws conclusions on business development based on the results of the analysis. The nine elements mapped in this research are 1) customer segments, 2) value propositions, 3) channels, 4) customer relationships, 5) revenue streams, 6) key resources, 7) key activities, 8) key partnerships, and 9) cost structures. The analysis results showed that Karya Nugraha Multipurpose Cooperative needs to develop a market that originally had only one main customer and was at risk of unstable income. In addition, Karya Nugraha Multipurpose Cooperative needs to develop the channel to reach the existing customers and get new customers. Further findings from this research showed that the risk of income instability obtained by Karya Nugraha Multipurpose Cooperative has only one income stream, i.e. the sale of pure milk. Based on this research, it is necessary to provide added value from pure milk products so that it can provide additional income.
\end{abstract}

\section{KEY WORDS}

Business model canvas, cooperatives, pure milk, animal husbandry.

The livestock sector is one of the agricultural sub-sectors that has a high strategic value, among others in meeting the needs of non-carbohydrate food which continues to increase due to the increase in population, an increase in the average population income, and job vacancy. The characteristics of geographical, ecological and land fertility conditions in several parts of Indonesia are suitable for the development of cow milk agribusiness. On the demand side, domestic milk production only supplies no more than 30 percent of the total demand whereas around 70 percent comes from imports. It shows that the opportunity to empower dairy cattle business to increase national milk production in an effort to reduce milk imports is still high.

Dairy cattle business faces challenges in its development. These challenges are triggered by the problems faced by dairy cattle, including it has limited capital, the business scale has not reached economies of scale, it is still traditional, livestock productivity is still low, the technology has not been implemented in an integrated manner and global competition with neighboring countries that market their products in Indonesia (Rahardi, 2003). To deal with these challenges, a place that can accommodate dairy farmers is required in order to increase business scale and be able to apply more modern technology to increase productivity of dairy cattle farms. One of the places to accommodate cow dairy farmers to increase the scale of their business is cooperatives.

One area that has cooperatives incorporated in the Indonesian Milk Cooperative Association (IMCA) is Kuningan District. Kuningan is a district in West Java Province which has a dairy cattle business that is quite developed supported by the availability of cooperatives and the milk processing industry. Dairy cooperatives are the place for members to run businesses as milk containers, concentrate feed providers, medical and animal health services. To optimize the production of cow's milk, a cooperative is made as a means to accommodate capital in order to increase the scale of production and also apply more modern technology. One of the cow milk cooperatives in Kuningan DIstrict is Karya Nugraha Multipurpose Cooperative.

As a dairy cow cooperative, Karya Nugraha is a cooperative located in Cigugur SubDistrict of Kuningan District. Karya Nugraha is one of the cooperatives that have joined IMCA. This cooperative is engaged in the absorption and distribution of dairy cow milk and 
has a main business unit; i.e. the sale of dairy cow milk. In 2016, this cooperative had 785 members and was the dairy cooperative with the most members in Kuningan District.

Karya Nugraha Multipurpose Cooperative's daily production of pure milk reaches 29,262 tons per day. Compared with several cooperatives that have a fairly similar production scale, Karya Nugraha Multipurpose Cooperative still sells pure milk products only to one partner; PT Ultra Jaya. This poses a high risk because once PT Ultra Jaya stops or reduces milk receipts from Karya Nugraha Multipurpose Cooperative, the revenue stream obtained by the Multipurpose Cooperative will be lost. Besides, Karya Nugraha Multipurpose Cooperative has not yet processed its pure milk so that it has not received optimal added value from the results of its main business.

Innovation and independence are part of the work of Karya Nugraha Multipurpose Cooperative which encourages the Multipurpose Cooperative to diversify its business. By optimizing their potential and seeing possible business opportunities, it is expected that the Multipurpose Cooperative can achieve its mission towards independence. To achieve the missions, it needs to be supported by the concept of the right business model by considering the opportunities and threats that will be faced as well as the strengths and weaknesses of Karya Nugraha Multipurpose Cooperative. Professional governance and setting goals that target profit and welfare of members have not been patterned. Therefore, in its implementation it is still based on the willingness of the cooperative members to manage it. The Multipurpose Cooperative needs to map out who will be served, what values will be offered to its customers, how can these values be distributed to customers, how to maintain relationships with customers, what resources are needed to produce these values, what activities are carried out and anyone who can help Karya Nugraha Multipurpose Cooperative so that the business model can run well as well as can consider the costs and revenues generated by the Multipurpose Cooperative.

Business development for Karya Nugraha Multipurpose Cooperative can be carried out effectively if the Multipurpose Cooperative managerial first knows how the business model is run in order to make the predetermined improvements to develop the main business units, i.e. the sale of pure milk and the development of pure dairy businesses in the future. Business model mapping is currently required by the Multipurpose Cooperative to improve the existing business models and develop new businesses to provide added value. This research applies a business model canvas developed by Osterwalder and Pigneur. Business model canvas is chosen because it can not only be used by profit-oriented companies but also for non-profit organizations. Through the nine elements of this model, improvements to existing business models and new business model prototype planning can be carried out. By making improvements to the existing business models, as well as innovating in new business models, it is expected that Karya Nugraha Multipurpose Cooperative can be a better organization in serving its members and competing with large companies both in productivity and in technology and efficiency.

Cooperatives have an important role in the development of the livestock sector in Indonesia. Similarly, Karya Nugraha Multipurpose Cooperative, as one of the cooperatives engaged in animal husbandry, nursery, collection and sale of pure cow's milk, needs to develop organizationally and functionally. Mapping the right business patterns and appropriate business development are needed by Karya Nugraha Multipurpose Cooperative in order to create profit as a basis for the distribution of the remaining business results for the welfare of its members. Currently, Karya Nugraha Multipurpose Cooperative is in a saturated position which is indicated by a decrease in the price of pure cow milk and the cost of production. If this condition continues, Multipurpose Cooperative will face financial problems. To anticipate these problems, Multipurpose Cooperative needs to do business development. Good business development can be arranged if Multipurpose Cooperative has known the current business model by looking at the organization's internal environment and business activities by using a business model canvas.

\section{LITERATURE REVIEW}

Business Model. There are various kinds of definitions of business models according to experts. Fuller and Morgan (2010) stated that the business model is an income formula, 
business system, and enterprise learning system. According to Wheelen and Hunger (2010), a business model is a method used to make money from a business environment where the company operates. Another understanding of business model is the method used to run a business so that companies can survive. Supriyadi (2006) explained that a business model is a concept that describes various business elements and their logical relationship in generating profitable and sustainable revenue streams. If it is viewed from its components, the business model consists of product components, benefits and income, customers, assets, knowledge, structure, and governance.

Business Model Canvas. Osterwalder and Pigneur (2010) explained that BMC is a business model framework in the form of a canvas and consists of nine boxes which are important elements that describe how organizations create and benefit for and from the customers. These nine elements are the development of 4 main areas in a business, namely customers, supply, infrastructure, and financial sustainability. The nine elements are: 1) customer segments, 2) value propositions, 3) channels, 4) customer relationships, 5) revenue streams, 6) key resources, 7) key activities, 8) key partnerships, and 9) cost structures.

Conceptual Framework. The research conducted with the object of Karya Nugraha Multipurpose Cooperative will be carried out by taking the pictures on the organization's business environment and activities by using nine elements of Business Model Canvas. By taking the pictures on 1) customer segments, 2) value propositions, 3) channels, 4) customer relationships, 5) revenue streams, 6) key resources, 7) key activities, 8) key partnerships, and 9) cost structures, it is expected that decision-making for the development of Karya Nugaha Multipurpose Cooperative business model can be carried out in a more targeted manner in accordance with the strengths and weaknesses of each element of Business Model Canvas of Karya Nugraha Multipurpose Cooperative.

\section{METHODS OF RESEARCH}

This research was conducted at Karya Nugraha Multipurpose Cooperative located in Cigugur Sub-District, Kuningan District, West Java. Data collection lasted for one month starting from October 2017-November 2017. This research uses two types of data consisting of primary and secondary data. The primary data were obtained from several respondents who had roles in Karya Nugraha Multipurpose Cooperative, among others, the chairman and board of Karya Nugraha Multipurpose Cooperative, and members of Karya Nugraha Multipurpose Cooperative. Moreover, the secondary data were obtained through the annual reports and documents of Karya Nugraha Multipurpose Cooperative, the Central Statistics Agency, the internet, books, journals, previous research and other data sources related to this research.

The stages applied in analyzing and processing data in this research are by mapping nine elements of Business Model Canvas to obtain a comprehensive picture of the business model run by Karya Nugraha Multipurpose Cooperative. These elements include: 1) customer segments, 2) value propositions, 3) channels, 4) customer relationships, 5) revenue streams, 6) key resources, 7) key activities, 8) key partnerships, and 9) cost structures. After the whole element is mapped, then the conclusion of the development of the business model is based on the potential of these elements.

\section{RESULTS AND DISCUSSION}

Identification of elements of the business model involves internal parties from Karya Nugraha Multipurpose Cooperative consisting of the chairman of Karya Nugraha Multipurpose Cooperative, the second chairman, secretary, head of administration and finance, and chairman of the supervisory section of Karya Nugraha Multipurpose Cooperative. These five respondents are assumed to have the ability and capacity to provide relevant information related to the data required to identify each BMC element. This internal party is also considered to have full authority in the formulation of what business models the organization is currently running and what ideas (inputs) can be used to develop a business model run by Karya Nugraha Multipurpose Cooperative. The results of the identification of 
the nine elements of BMC in Karya Nugraha Multipurpose Cooperative currently are as follows:

1. Costumer Segments. There are several customers served by Karya Nugraha Multipurpose Cooperative. The main customer is Ultra Jaya's milk processing industry as one party that takes about ninety percent of pure cow's milk production from Karya Nugraha Multipurpose Cooperative. In carrying out its daily production, Karya Nugraha Multipurpose Cooperative has delivered pure milk twice each day which is received entirely by Ultra Jaya only if the quality of the milk delivered by Karya Nugraha Multipurpose Cooperative is in accordance with the milk quality limit determined by Ultra Jaya. In addition to Ultra Jaya, as the main customer, there are also retail buyers who buy directly from Karya Nugraha Multipurpose Cooperative. Although these retail buyers are small in number, they can increase revenue from Karya Nugraha Multipurpose Cooperative because this retail buyer buys milk produced by the Multipurpose Cooperative whose prices is determined by the Multipurpose Cooperative which is higher than the purchase price of Ultra Jaya. The last customer served by Karya Nugraha Multipurpose Cooperative is a member of Karya Nugraha Multipurpose Cooperative. Overall, the members of this cooperative are farmers who do not generate income streams for the Multipurpose Cooperative, but the existence of these members is very important as the supplier of milk sold by the Multipurpose Cooperative with reciprocal services provided by Karya Nugraha Multipurpose Cooperative to assist farmers in the process of producing cow milk.

2. Value Propositions. Karya Nugraha Multipurpose Cooperative currently offers different value propositions and is adjusted to its customers, including:

a. Ultra Jaya. Karya Nugraha Multipurpose Cooperative, which has a cooperative relationship in terms of sellers and buyers with Ultra Jaya, has a value proposition offered in the form of quality cow's milk which is in accordance with the standards determined by Ultra Jaya. As a cow milk processing company, Ultra Jaya maintains its quality so that if there is a decrease in the quality of milk from Karya Nugraha Multipurpose Cooperative, it will reduce Ultra Jaya's trust to Karya Nugraha Multipurpose Cooperative and will pose a risk of terminating the sale and purchase relationship between them. In addition to quality, Karya Nugraha Multipurpose Cooperative needs to maintain the quantity every delivery period so that there is no sudden significant change in the amount because it will affect the processed milk production process that is carried out by Ultra Jaya.

b. Members of Karya Nugraha Multipurpose Cooperative. In 2016, Karya Nugraha Multipurpose Cooperative had 785 members. The number of members increased by about eight percent compared to the number of cooperative members in 2015. The value proposition offered by Karya Nugraha Multipurpose Cooperative to its members is, among others, the guarantee that milk produced by members will be purchased by cooperatives in accordance with the quality of milk produced from each farmer. In addition, the cooperative provide services in the form of sales of feed, livestock equipment, medical services, and artificial insemination for farmers with a payment scheme using a cutting system from a portion of the farmers' milk production which is deposited to Karya Nugraha Multipurpose Cooperative so that it does not burden the farmers in the service payment process.

c. Retail Buyer. Compared to Ultra Jaya, retail buyers have a small purchasing portion which is under ten percent of the total production of pure milk of Karya Nugraha Multipurpose Cooperative. However, those retail buyers still have a role in increasing the income of Karya Nugraha Multipurpose Cooperative. The value proposition offered by Karya Nugraha Multipurpose Cooperative to the retail buyers is basically the same as Ultra Jaya.

3. Channels. In communicating value propositions to its customers, Karya Nugraha Multipurpose Cooperative uses the word of mouth method (conveying information by word of mouth) and by using telephone services, text messages, and conducting face-to-face meetings with group leaders regularly. The communication method is used to inform if there is a schedule change in milk collection from each temporary milk storage area in each region in order to condition and maintain optimal milk quality. In addition, Karya Nugraha Multipurpose Cooperative has joined the IMCA (Indonesian Milk Cooperative Association), which aims to inform the general public about the development and existence of Karya Nugraha Multipurpose Cooperative. Karya Nugraha Multipurpose Cooperative already has its own website whose content is in the form of information on activities carried out by Karya 
Nugraha Multipurpose Cooperative, the number of members, as well as various other information relating to the development of Karya Nugraha Multipurpose Cooperative. However, this website is still not optimally managed. It can be seen from the last update made by Karya Nugraha Multipurpose Cooperative which still contains information in 2016 and there has been no information update on activities or general information on developments related to Karya Nugraha Multipurpose Cooperative.

4. Customer Relationships. The type of relationship made by Karya Nugraha Multipurpose Cooperative along with its customers is a personal relationship, in which the relationship is based on direct interaction. Karya Nugraha Multipurpose Cooperative has a different personal relationship with each of its customers, especially to its members. The relationship between Karya Nugraha Multipurpose Cooperative and Ultra Jaya is conducted by delivering the pure milk purchased by Ultra Jaya accompanied by checking the quality of milk and the volume of milk delivered by Multipurpose Cooperative. The relationship between Multipurpose Cooperative and its members is carried out by providing guidance to members and prospective members on how to carry out the process of dairy farming properly, in terms of cattle selection, feed selection, and cattle care to produce pure milk that has good quality. In addition, Multipurpose Cooperative offers feed services, artificial insemination, animal husbandry equipment and treatment for members with affordable prices and payment schemes. Thus, members do not need to experience difficulties in finding daily needs in the livestock process. In addition, Karya Nugraha Multipurpose Cooperative prepares livestock groups in each sub-district which function as temporary shelters for cow's milk from farmers so that farmers do not need to bring their own pure milk and reduce the risk of damaged milk on the road outside the supervision of Karya Nugraha Multipurpose Cooperative. This livestock group also aims to gather the needs and aspirations of the farmer members to accommodate the needs of farmers in each sub-district more optimally. In addition, at the end of each year, Karya Nugraha Multipurpose Cooperative always conducts End of Year Meetings which aim to convey to members about the development of cooperatives in one year, discuss the direction of cooperative development that is expected by members for the next year, and share the surplus to its members.

5. Revenue Stream. Karya Nugraha Multipurpose Cooperative's revenue stream comes from the sale of Multipurpose Cooperative pure milk to Ultra Jaya and retail buyers who come to Karya Nugraha Multipurpose Cooperative. There is no income stream from cooperative members because the target of Karya Nugraha Multipurpose Cooperative for the members is to provide services without seeking benefits from them. The advantage gained from members is to get decent facilities in the farm process. Dairy cows cared for by the farmers are expected to provide increased production. This will increase the overall production of Karya Nugraha Multipurpose Cooperative and provide a higher revenue stream from the sale of pure milk. However, the collaboration of Karya Nugraha Multipurpose Cooperative, which only relies on one company, i.e. Ultra Jaya, provides a very high risk. Once a contract is terminated from Ultra Jaya to Multipurpose Cooperative, then Multipurpose Cooperative will lose its main income stream and will risk Multipurpose Cooperative's financial performance. It needs to be reconsidered to do additional cooperation or add value to the Karya Nugraha Multipurpose Cooperative final product in order to get a new source of revenue stream.

6. Key Resources. To run its business model, Karya Nugraha Multipurpose Cooperative has several main resources in the form of physical, intellectual and human resources.

a. Physical Resource. Currently, the physical resources owned by Karya Nugraha Multipurpose Cooperative include 1 unit of secretariat office, 3 units of cooling machine, 1 tank truck for pure milk transport, and 8 pick-up trucks for pure milk transport from the livestock group office to the refrigeration unit.

b. Intellectual Resource. Karya Nugraha Multipurpose Cooperative has a year-end report book whose contents are quite detailed including the structure of the Karya Nugraha Multipurpose Cooperative board of directors, the number of members and the area where they live, the number of cows, the average monthly production of members, the total number of cows, the performance report of Karya Nugraha Multipurpose Cooperative, as well as the details of the obligation and the distribution of surplus to its members. 
c. Human Resource. Karya Nugraha Multipurpose Cooperative has an organizational structure that includes several management functions required by cooperatives. The management structure of Karya Nugraha Multipurpose Cooperative consists of chairman, first chairman, second chairman, secretary, treasurer, and supervisory section. In carrying out its business processes, Karya Nugraha Multipurpose Cooperative is accompanied by a financial manager appointed by the Office of Cooperatives and SMEs with the aim of maintaining the financial performance of Karya Nugraha Multipurpose Cooperative to remain in the expected position and purpose.

7. Key Activities. The main activities carried out by Karya Nugraha Multipurpose Cooperative in order to make the business model run well include: conducting training for new members who will join Karya Nugraha Multipurpose Cooperative about how to take care of farms in order to provide optimal results; in addition, Karya Nugraha Multipurpose Cooperative controls the quality of milk production for each farmer in order to monitor the routine production of each farmer and also to check the production quality of each farmer, which later, pure milk produced by each farmer will be accumulated and sent to Ultra Jaya as the main customer of Karya Nugraha Multipurpose Cooperative; control routine care for cows owned by the members; and perform other services needed by members in order to obtain optimal results and aim to increase revenue from Karya Nugraha Multipurpose Cooperative.

Table 1 - Business Model of Karya Nugraha Multipurpose Cooperative

\begin{tabular}{|c|c|c|c|c|}
\hline \multirow[t]{2}{*}{$\begin{array}{c}\text { Key Partnerships } \\
\text { Multipurpose Cooperative } \\
\text { Members } \\
\text { Department of } \\
\text { Cooperatives and SMEs } \\
\text { Financial Institution } \\
\text { Supplier of livestock } \\
\text { supporting equipment }\end{array}$} & $\begin{array}{c}\text { Key Activities } \\
\text { Training for new } \\
\text { members } \\
\text { Product quality } \\
\text { control } \\
\text { Product distribution } \\
\text { Cows care } \\
\text { Livestock } \\
\text { supporting } \\
\text { services }\end{array}$ & \multirow[t]{2}{*}{$\begin{array}{l}\text { Value Propositions } \\
\text { Milk quality and quantity } \\
\text { Guaranteed purchases } \\
\text { based on the quality } \\
\text { Member services }\end{array}$} & $\begin{array}{c}\text { Costumer Relationships } \\
\text { Distribution and quality } \\
\text { control } \\
\text { Training and service } \\
\text { Livestock groups } \\
\text { Year-end meeting }\end{array}$ & \multirow[t]{2}{*}{$\begin{array}{c}\frac{\text { Costumer }}{\text { Segments }} \\
\text { Ultra Jaya } \\
\text { Cooperative } \\
\text { members } \\
\text { Retail buyers }\end{array}$} \\
\hline & $\begin{array}{l}\frac{\text { Key Resources }}{\text { Physical resources }} \\
\text { Year-end report } \\
\text { book } \\
\text { Human resources }\end{array}$ & & $\begin{array}{l}\text { Word of mouth and IT } \\
\text { Indonesian Milk } \\
\text { Cooperative Association }\end{array}$ & \\
\hline \multicolumn{3}{|c|}{$\begin{array}{l}\text { Cost Structures } \\
\text { costs for the operations Karya Nugraha Multipurpose } \\
\text { Cooperative } \\
\text { Operational costs of transporting pure milk } \\
\text { Cost for holding a year-end meeting }\end{array}$} & \multicolumn{2}{|l|}{$\frac{\text { Revenue Streams }}{\text { Pure milk sale }}$} \\
\hline
\end{tabular}

8. Key Partnership. The process of developing Karya Nugraha Multipurpose Cooperative, as a cow milk production cooperative, is inseparable from the collaboration carried out by Karya Nugraha Multipurpose Cooperative with its members as suppliers of pure milk for the Multipurpose Cooperative and partnering with the Cooperatives and SMEs Office to monitor the development direction of Karya Nugraha Multipurpose Cooperative so that it is inseparable from the cooperative values. Karya Nugraha Multipurpose Cooperative also partnered with financial institutions that provide loans to develop the businesses and also supply other livestock in the form of feed, animal husbandry, and medicines that are used to support the livestock process of members who have not been able to independently carry out the production.

9. Cost Structure. Running a business model in inseparable from the costs that must be incurred. The cost structure relies heavily on the management of key resources, key activities, and key partnerships that are built to facilitate the business model. includes:

The cost structure of Karya Nugraha Multipurpose Cooperative business activities

- Routine operational costs of Karya Nugraha Multipurpose Cooperative include the salary of the chairman, secretary, treasurer, and employees who work at the secretariat of Karya Nugraha Multipurpose Cooperative. The operational costs in the form of electricity, water and office administration tools are also part of the costs that need to be spent by Karya Nugraha Multipurpose Cooperative. 
- Operational costs for the collection and delivery of pure milk to customers as well as the cost of the maintenance of the transport vehicle and maintenance of refrigeration for the pure milk (cooler).

The cost for holding a year-end meeting conducted by the cooperative at the end of the period aims to report on the annual results that have been running and discuss the development plans of Karya Nugraha Multipurpose Cooperative in the coming year with its members.

\section{CONCLUSION}

The findings of this research indicate that Karya Nugraha Multipurpose Cooperative has been able to segment the customers. However, customer limitations have made Karya Nugraha Multipurpose Cooperative experience a weak bargaining position so that the selling price of pure milk received by Karya Nugraha Multipurpose Cooperative is still greatly influenced by the decision of the buyer. In addition, by only having one main customer, Karya Nugraha Multipurpose Cooperative faces the risk of decreasing income if one day the customer decreases the quota of the purchase.

Karya Nugraha Multipurpose Cooperative delivers its value to customers through traditional methods of word of mouth so that information is vulnerable to not being conveyed to its customers. In addition, this traditional delivery method can hinder the development of Karya Nugraha Multipurpose Cooperative.

The revenue stream owned by Karya Nugraha Multipurpose Cooperative is still limited to selling pure milk only without any other income streams. If Karya Nugraha Multipurpose Cooperative does not develop its revenue stream, it is possible that there will be stagnation in the development of its business model because there is an increase in production costs without being followed by an increase in the income.

\section{SUGGESTIONS}

Karya Nugraha Multipurpose Cooperative needs to develop a market that aims to improve its bargaining position and reduce the risk of failure in selling the pure milk produced by farmers and increase revenue flow by increasing the scale of production to be more efficient.

Karya Nugraha Multipurpose Cooperative needs to develop its channel so that it can be more efficient in conveying its values to the customers. The increasing channel of Karya Nugraha Multipurpose Cooperative is expected to be able to explore new markets to develop.

Karya Nugraha Multipurpose Cooperative needs to develop pure dairy products that aim to provide added value and increase the income earned.

\section{REFERENCES}

1. Rahardi, F. 2003. Agribisnis Peternakan. Edisi Revisi. Penebar Swadaya. Jakarta.

2. Baden-Fuller, C. (2010) Business Models as Models. Long Range Planning, 43, 156-171.

3. Wheelen, Thomas L., Hunger, J. David, (2010) Strategic Management and Business Policy Achieving Sustainability. Twelfth Edition. Pearson.

4. Supriyadi. 2006. Perlukah Mendesain Business Model Baru? Jurnal Manajemen Prasetya Mulya. XX (90).

5. Osterwalder, Yves. Pigneur, Smith, Alan and et al. 2010. Business Model Generation. Self published, Modderman Drukwerk, Amsterdam, the Netherland. 